\title{
UPAYA PENANGANAN KHUSUS NARAPIDANA LANSIA SEBAGAI KELOMPOK RENTAN
}

\section{Elika Sifra Lidya, Mitro Subroto}

Politeknik Ilmu Pemasyarakatan, Indonesia

Email: elikasifra@gmail.com, subrotomitro07@gmail.com

\begin{abstract}
Abstrak
LAPAS atau Lembaga Pemasyarakatan dibawah naungan Direktorat Jendral Pemasyarakatan adalah tempat akhir dari proses sistem peradilan pidana yang membina serta mereintegrasi sosial terpidana,agar ketika kembali ke masyarakat mereka mampu menjalani kehidupan normal. Lansia (menurut UU No. 13 Tahun 1998: Lansia) adalah orang yang umurnya mencapai usia 60 tahun ke atas. Dalam upayanya Pemasyarakatan memaknai pengertian ini dengan mengatur hak narapidana yang tertuang dalam UU no 12 tahun 1995 pasal 14 ayat 1.Usia yang kian tinggi dan kondisi tubuh yang menurun tentu narapidana lansia membutuhkan penanganan khusus baik secara kesehatan,perlakuan,dan pelayanan publik. Narapidana lansia sebisa mungkin diperlakukan sebagai mana masyakarat biasanya,hanya saja tempat dan penerapannnya yang berbeda.Hal ini guna implementasi bagian dari Hak Azasi Manusia (HAM) sebagai instrumen nasional.Upaya penanganan khusus ini melibatkan stakeholder lainnya baik itu medis atau tenaga kesehatan dan pihak pemerintahan guna mendukung sara prasarana yang dibutuhkan.Lansia sebagai salah satu dari kelompok rentan menjadi objek penting dalam hal bagaimana penangan yang layak agar mereka merasa dipedulikan di usia mereka yang senja.Walaupun hingga kini masih dalam proses dan tahapan penyempurnaan penanganan khusus bagi mereka.Faktanya masih belum optimal dan penelitian ini menggambarkan sudah seberapa baik upaya tersebut.
\end{abstract}

Kata Kunci: Narapidana Lansia; Kelompok rentan; Hak Azasi Manusia

\section{Abstract}

LAPAS or Correctional Institution under the auspices of the Directorate General of Corrections is the final place of the criminal justice system process that fosters and integrates the social of convicts, so that when returning to society they are able to live a normal life. Elderly (according to Law No. 13 of 1998: Elderly) is a person whose age reaches the age of 60 years and above. In its efforts, Correctional Services interpret this understanding by regulating the rights of inmates contained in Law no. 12 of 1995 article 14 paragraph 1.The increasing age and declining body condition of the elderly inmates need special treatment both in health, treatment, and public services. Elderly inmates as much as possible are treated as people usually are, it's just that the place and application are different. This is for the implementation of part of Human Rights (HAM) as a national instrument. This special handling effort involves other 
stakeholders be it medical or health workers and the government to support the infrastructure needed. The elderly as one of the vulnerable groups become important objects in terms of how decent handlers are so that they feel cared for in their twilight years. Although until now still in the process and stages of refinement of special handling for them. The fact is still not optimal and this study illustrates how well the effort is.

Keywords: Elderly inmates; Vulnerable groups; Human Rights

Diterima: 21-11-2021 Direvisi: 12-12-2021

Diterbitkan: 20-12-2021

\section{Pendahuluan}

Indonesia merupakan negara hukum yang memiliki proses dalam serangkaian penegakan hukum yang berjalan apakah regulasinya sesuai dengan rancangan progja atau tidak.Berdasarkan ketentuan yang tercantum pada pasal 1 ayat (3) UUD RI Tahun 1945 bahwa sejatinya sebagai negara hukum,Indonesia yang giat menegakkan tertib hukum dengan tujuan Negara mewujudkan masyarakat yang adil makmur berdasarkan Pancasila (Moeljatno, 2021). Namun dalam upaya tersebut kehidupan manusia tidak terlepas dari kesalahan dan banyak diantaranya berkembang menjadi pelaku kejahatan sehingga harus menempuh jalur hukum karena mungkin mereka kurang beruntung atau memang sewajarnya mereka menerima sanksi atas perbuatannya.

Sanksi berupa pidana yang diderita menimbulkan rasa sakit yang menjiwa. Tidak dapat dipungkiri bahwa jika sanksi yang diberi hanya berupa teguran dan peringatan saja mungkin beberapa pelaku kejahatan di dunia akan selalu mengulang pelanggaran hukum yang ia perbuat,maka dari itu penting dan dirasa butuh penerapan sanksi pidana sebagai upayamenciptakan kehidupan masyarakat yang aman dan tertib. Pemidanaan sebagai realisasi hukum pidana yang menimbulkan rasa sakit atas perilaku melanggar hukum.

Pidana penjara atau kurungan meruakan salah satu jenis penghukuman yang dikenakan kepada pelaku tindak pidana baik mereka berusia muda,tua, bahkan lanjut usia. Terpidana di tempatkan di Lembaga Pemasyarakatan dengan status narapidana guna menjalani proses hukum yang berlaku dan setelah ia menyelesaikan hukuman tersebut sangat diharapkan ia mampu kembali ke masyarakat sebagaimana mestinya. Sanksi pidana mengakibatkan penderitaan akibat perbuatan pelaku kejahatan dan kerap kali implementasi pelaksanaan sanksi pidana faktanya di lapangan sangat tidak semua di realisasikan dengan benar dan tidak semua pelaku kejahatan hanya dapat diberi teguran dan larangan ringan saja,karena menerka juga perlu dan harus disadarkan terhadap kejahatan merea.Adapun tujuan sanksi pidana sebagai pencegah dan menerapkan kesejahteraan bermasyarakat yang aman, tertib, dan tentram apalagi tmelihat situasi bahaya yang harus segera di amankan.

"Pidana merupakan penjamin dan pengancam utama bagi kebebasan dan kemerdekaan manusia, apabila hal tersebut digunakan dengan cermat, hemat, dan secara manusiawi. Hal tersebut bisa menjadi pengancam apabila digunakan dengan paksa dan secara sembarangan.” (Panjaitan, 2009). 
Kini jumlah tahanan dan narapidana di Indonesia lanjut usia setiap tahunnya bertambah dan kadang juga mengalami penurunan jumlah,oleh sebab itu Lapas sebagai tempat pelaksanaa pembinaan Narapidana dan Anak Didik Pemasyarakatan memberikan hak mereka sesuai Undang-undang No. 12 tahun 1995. Di lingkungan Pemasyarakatan terdapat kelompok yang disebut sebagai Kelompok Rentan yakni mereka yang di kategorikan rentan bagi dari segi usia, kerentanan akan penyakit,kondisi fisik, mental, mereka yang minoritas seperti Narapidana Wanita, Andikpas, Lansia dan kaum minoritas (Walukow, 2013). Berikut pengertian Kelompok Rentan:

1. Menurut UU Republik Indonesia

Yang dimaksud Kelompok rentan ialah mereka yang lanjut usia, anak-anak, fakir miskin, perempuan hamil, dan orang dengan Disabilitas.

2. Yasonna Laoly, Menteri Hukum dan Hak Asasi Manusia

Menyatakan bahwa Kelompok rentan adalah perempuan, anak, orang dengan Disabilitas, dan masyarakat hukum adat.

Pelaku tindak pidana dalam Lembaga Pemasyarakatan tidak hanya narapidana yang berusia muda atau remaja tetapi juga ada yang lanjut usia. Dilihat dari usia jelas menunjukan kondisi fisik dan mental dimana seiring berjalannya waktu semakin dan tidak baik jika dibanding dengan orang lain umumnya.Setiap orang memiliki khas yang berbeda-beda di masa usia lanjutnya,sehingga sulit untuk menggambarkan bagaimana kondisinya,bagaimana keadaan batiniahnya bahkan kebutuhan fisiknya.

Dikarenakan melonjaknya angka jumlah lanjut usia dibandingkan dengan jumlah kelompok muda atau biasa disebut Aging society berefek pada tingginya jumlah narapidana lanjut usia, mengingat adanya kesenjangan sosial, diskrimanasi umur atau kondisi lingkungan yang kurang menerima keberadaan mereka sehingga terjadi penyelewengan yang menuntut mereka berakhir di pengadilan. Disebut lanjut usia tentu terdapat masalah hidup mulai dari ketergantungan terhadap individu lainnya,merasa diri kurang berguna,selain itu adanya keterbatasan fisik yang sangat ketat, dan perasaan terisolasi. Di usia yang kian rentan akan menghadapi berbagai macam persoalan kondisi emosional yang tidak stabil memicu mereka bergerak diluar kendali,hingga dapat melakukan tindakan kejahatan yang dipicu emosi.

Lanjut Usia merupakan golongan masyarakat yang lemah dimana pada fase ia mengalami penurunan kemampuan fisik dan akal yang di mulai dengan adanya tanda perubahan dalam hidup. Maka sebagai bagian dari warga binaan pemasyarakatan dalam Lembaga Pemasyarakatan, lansia sebaiknya diberi pola pembinaan dan perhatian khusus dalam artian penanganan dalam kondisi kritis dan urgensi karena mereka semakin mengalami penurunan kemampuan diri dan kegesitan pergerakan yang tentu berbeda dengan narapidana muda atau remaja (Sitepu, 2021). Di samping itu, pemberian fasilitas sehari-hari yang memadai dan kedudukan yang istimewa dalam tiap peran sosialnya merupakan salah satu pilar terpenting dalam rangka melakukan pembinaan dan perawatan yang efektif bagi narapidana lanjut usia.

Undang-Undang Nomor 13 Tahun 1998 tentang Kesehjateraan Lanjut Usia menyatakan jika lansia adalah seseorang yang telah berusia 60 tahun ke atas yang 
kisaran 60 hingga 70 tahun ke atas serta diikuti penurunan kesehatan dan keterbatasan fisik,sehingga diperlukan perawatan sehari-hari yang cukup (Akbar, 2019).

Sedangkan WHO atau World Health Organization mengklasifikasikan empat golongan yakni:

1. Usia pertengahan (middle age), yaitu kelompok usia 45 sampai 59 tahun

2. Lanjut usia (elderly) : antara 60 sampai 74 tahun

3. Lanjut usia tua (old) :antara 75 sampai 90 tahun

4. Sangat tua (very old): di atas 90 tahun .

Terbukti bahwa narapidana lansia memang membutuhkan perhatian khusus dari pemerintah yakni dengan dikeluarkannya PERMENKUMHAM Nomor 32 Tahun 2018 tentang Perlakuan bagi Tahanan dan Narapidana Lanjut Usia. Istilah perlakuan khusus pada undang-undang tersebut diartikan sebagai upaya yang ditujukan untuk memberikan kemudahan pelayanan guna membantu narapidana lansia dalam memulihkan dan mengembangkan diri agar dapat meningkatkan taraf kesejahteraan sosialnya (Dimas, 2021).

\section{Metode Penelitian}

Jurnal ini derdasarkan metode penelitian kualitatif yang sifat penulisannya berupa penggambaran dan pemaparan permasalah secara deskriptif dimana dalam prosedur penulisannya berupa tulisan ilmiah dan dikaji ulang dari lisan seseorang sehingga hasil akhirnya berupa tulisan yang berisi pemahaman,ide, opini serta fakta yang terjadi dilapangan. Adapun metode penelitian kualitatif pada jurnal ini secara deskriptif mencakup observasi menggambarkan suatu permasalahan, sebagai pemahaman baru menggunakanbentuk bahasa alamiah serta memanfaatkan berbagai metode ilmiah.

Dalam analisis data yakni proses mencari dan menyusun secara sistematis baik itu hasil wawancara,pengumpulan data dari internet,catatan lapangan sehingga dapat dengan mudah dipahami, dan hasil penelitian dapat diinformasikan kepada orang lain (Sugiyono, 2013).

Penulisan jurnal ini berdasarkan pendekatan deskriptif melalui undang-undang yang berkaitan dengan judul dan isi jurnal serta memberikan upaya alternatif pemecahan masalah berdasarkan data bertujuan untuk memdapatkan informasi mengenai penangan dan perlakuan khusus bagi kelompok rentan di Lembaga Pemasyarakatan (Ernis, 2017). Setelah di kaji secara kualitatif yakni pemaparan berdasrkan fakta lapangan, dokumentasi dan observasi maka diikuti dengan menggambarkan bagaimana solusi dan penanganan permasalahnya. Penulis juga memperhatikan bagaimana bahan tulisan disesuaikan dengan sumber bacaan lainnya,keselarasan media dan argemntasi penulis lainnya serta bahan buku bacaan hukum dan peraturan yang menjadi sumber penulisan. 


\section{Hasil dan Pembahasan}

\section{Konsep Dasar Pemasyarakatan terhadap Kelompok Rentan Lansia}

Pemasyarakatan dibawah naungan Kementrian Hukum dan HAM mengkonsepsikan bagaiamana memperlakukan narapidana sesuai dengan rules yabng berlaku.Sejak 1964 lalu Pemasyarakatan menunjukkan proses melalui konferensia kepenjaraan dan berlanjut hingga akhirnya di sahkan UU Pemasyarakatan oleh Presiden Republik Indonesia tertuang dalam Undang-undang No.12 Tahun 1995. (Pasal 2 undang undang nomor 12 tahun 1995) Tentang Pemasyarakatan dijelaskan bahwa

"Sistem Pemasyarakatan diselenggarakan dalam rangka membentuk Warga Binaan Pemasyarakatan agar menjadi manusia seutuhnya menyadari kesalahan, memperbaiki diri dan tidak mengulangi tindak pidana sehingga dapat diterima kembali oleh lingkungan masyarakat dapat aktif berperan dalam pembangunan dan dapat hidup secara wajar sebagai warga yang baik dan bertanggung jawab." (Nur, 2017)

Walapun pada dasarnya pemidanaan adalah jalan terakhir bagi pelaku tindak kejahatan dan mencegah kriminalisme (Wiyanto, 2012). Dalam upaya penerapan Sistem Pemasyarakatan ini yakni mengedepankan hak-hak narapidana,baik layanan kesehatan dan pembinaan dimana diharapkan mampu melahirkan perilaku positif yang baru bagi narapidana.

Pelaku tindak kejahatan atau narapidana di dalam Lembaga Pemasyarakatan tidak hanya usia muda dan produktif,disana juga terdapat orangtua yang sudah lanjut usia. Maka pemasyarakatan berkolaborasi dengan pemerintah menanggapi bagaimana mereka di perlakukan,memperhatikan konsep dasar Pemasyarakatan lainnya yang mengutamakan Narapidana lansia dan juga Lansia yang disabilitas atau sakit dan berkebutuhan khusus dan yang sebenarnya kurang layak untuk tetap berada di dalam Lapas. Dari satu sudut pandang,anggap saja Lapas sebagai suatu subjek lembaga korektif (RAMIDHA, 2011) yang aktif menjalankan perannya mereintegrasi sosial dimana program pembinaan adalah yang terpenting.

Bagi Narapidana yang dinyatakan jompo (Menurut UU No. 4 tahun 1965 pasal 1) atau lanjut usia ketika seseorang mencapai umur 55 tahun, mengalami penuaan fisik dan psikis kemudian tidak mempunyai atau tidak berdaya mencari nafkah sehari-hari sehingga menerima nafkah dari orang lain (Dewi, 2019). Kini, berlaku UU No. 13 tahun 1998 tentang kesejahteraan lansia bahwa lansia adalah seseorang yang mencapai usia 60 tahun ke atas mendekati akhir siklus kehidupan manusia di dunia sampai akhir kehidupannya. Sedangkan pada PP No.31 dijelaskan bagaiamana kelayakan narapidana diberikan pembinanaan.

Pembinaan oleh Pemasyarakatan yang nantinya dapat mengembalikan kesatuan relasi atau realitionship yang pernah hilang sehingga masyarakat dapat menerima mereka kembali.Maka dari itu Pemasyarakatan sangat memperhatikan keselarasan antara UU No.13 tahun 1998 tadi dengan Narapidana Lansia.

Aturan Standart Minimum bagi tahanan oleh Kongres PBB sebagai regulasi pencegahan dan penanganan Narapidana di Jenewa tahun 1955 untuk menggambarkan secara rinci sistem dan rules Lembaga Pemasyarakatan menetapkan apa yang umumnya 
diterima sebagai prinsip dan praktik yang baik dalam perlakuan terhadap tahanan dan pengelolaan institusi.

PBB sebagai bagan internasioanl juga turut memperhatikan narapidana lansia, Tentunya Indonesia sangat mengharapkan kerja nyata PBB dalam mendukung lewat bantuan secara organisasi internasional agar dapat segera mengesahkan Jakarta Rules mengingat Tokyo Rules dan Bangkok Rules yang sudah ada karena dianggap penting untuk mendorong pemberlakuan standard internasional untuk kebijakan khusus terkait perlakuan terhadap narapidana dan tahanan lanjut usia.Selain itu, kategorisasi tahanan sebagai pembeda yangmana harus ditempatkan di Lembaga atau bagian lembaga yang terpisah dengan memperhatikanjenis kelamin, usia, catatan kriminal mereka, alasan hukum untuk penahanan mereka dan kebutuhan perawatan mereka.

Komponen Kelompok Rentan yang dimaksud adalah anak yang berhadapan dengan hukum,disabilitas, perempuan,dan Lansia yang dialokasikan dan ditempatkan terpisah.SMR ini juga mengatur bagaimana tahanan atau narapidana usia muda harus dipisahkan dari orang dewasa,karena dinilai kurang baik serta rentan akan diskriminasi kemampuan fisik di lingkungan pemasyarakatan.

Pemasyarakatan memperhatikan unsur kesehatan WBP lansia yang mengalami penurunan kinerja organ tubuh,sendi, dan otot yang menimbulkan terganggunya keseimbangan postur tubuh. Oleh karena itu kini PERMENKUMHAM tentang bagaimana perlakuan terhadap narapidana lansia telah dirancang yang kemudian akan di tetapkan menjadi The Jakarta Rules di PBB nanti (Indonesia, 2018).

Narapidana lansia yang sudah tidak produktif lagi tentu akan sangat terbatas ruang geraknya,maka pola pembinaannya pun harus di sesuaikan,karena sudah tidak memungkinkan lagi untuk kabur atau melarikan diri. Selanjutnya yang ia butuhkan adalah perawatan dan perhatian maka dari itu Pemasyarakatan memberi akses bagi keluarga untuk turut memberi perhatian baik lewat layanan kunjungan,kebutuhan pangan dan sandangnya serta ruang perhatian lainnya.

Memang selama ini Narapidana lansia masih di tempatkan satu lokasi dengan Narapidana umum lain yang hukumannya panjang. Suda terdapat beberapa Lapas yang menerapkan perlakuan khusus bagi lansia tapi Pemasyarakatan memandang belum cukup sampai disana,dan masih perlu banyak pembenahan.Dianggap penting dari sudut pandang bagaimana sistem asimilasi secara berkala dengan menempatkan mereka di rumah sebagai tempat pembinaan napi lansia,yang membutuhkan ruang lingkup sosial yang lebih layak dan nyaman.

Sedangkan jika ditempatkan di dalam Lapas maka Narapidana lanjut usia membutuhkan pembinaan yang sedikit lebih diistimewakan dan harus optimal.

\section{Perlakuan Khusus Narapidana Lansia}

Pemahaman tentang perlakuan adalah bagaiaman seseorang terhdap objek lainnya berinteraksi dan saling memberi respon satu sama lain lebih tepatnya tindakan dan perbuatan yang di berikan sebagai aksi terhdap satu individu maupun objek. Kemudian kaitannya dengan kekhususan terhadap narapidana Lansia pula,yang 
dimaksud khusus katakanlah sedikit lebih istimewa dan lebih optimal dibanding narapidana produktif lainnya.

Tentunya dalam perlakuan khusus ini harus memenuhi persyaratan dan mekanisme yang disepakati bersama dan ditujukan bagi mereka yang rentan. Rentan yang dimaksudkan karena mereka rapuh akan kesehatannya,rentan mudah terkena penyakit, sudah tidak produktif untuk bekerja dan menghasilkan karya,terdapat kecacatan mental, penyandang disabilitas, dan terakhir orangtua lansia.Baik secara psikis,logika dan mental mereka sudah tidak seaktif narapidana umum,mereka rentan dengan tindakan diskriminasi, pelecehan dan dikucilkan ketika berada di lingkungan Lapas karena mereka sulit untuk cepat bergerak, lamban dan lambat dalam beraktifitas,mereka juga mulai kurang pendengaran dan ingatan.

Pada kenyataannya semua orang mengalami pertumbuhan dan perkbangan, dimana perkembangan itu sendiri berupa perubahan karakter, sifat dan kepribadian seseorang serta kondisi kejiwaan dan psikologis seseorang sehingga lebih memaknai hidup mereka dalam tatanan social yang lebih besar di masa depan (Papalia et al., 2007). Bagi narapidana lansia perempuan mengalami menopouse tentunya ada perubahan horman sehingga penting mereka di perlakukan khusus.

\section{a. Perawatan Narapidana Lansia}

Perawatan bagi lansia di lingkungan pemasyarakatan menjadi satu program penting demi kesejahteraan Narapidana Lansia. Perawatan bagi lansia ini berkaitan dengan jumlah kuantitas narapidana lansia di Indonesia. Perawatan lansia dan kenaikan jumlah lansia seharusnya dilekasakan seimbang dan sama-sama meningkat,maksudnya adalah jika jumlah lansia di lingkungan Pemasyarakatan bertambah maka perawatanpun harus esktra dan ditingkatkan pula. Namun jika jumlahnya saja yang meningkat tanpa memperhatikan perawatannya maka akan terjadi ketidaksejahteraan lansia di dalam Lapas. Mengingat kondisi dalam Lapas yang tentunya menambah permasalahan diri yang semakin signifikan dan bervariasi dan walaupun umumnya orangtua lansia lebih banyak bergantung dengan kehidupan orang lain.

Langkah atau tindakan normatif yang dilakulakn pemerintah dalam merespon kebutuhan lansia akan perawatan adalah lewat perumasan UU No.13 tahun 1998 tersebut yang mana seluruh kesatuan bagaiamana kesejahteraan Lanjut Usia. Dengan adanya Undang-undang ini meregulasi keseluruhan Indonesia maupun daerah guna mendukung terealisasinya kesejahteraan Lansia dibuatkan dalam bentuk program keseharian lansia di dalam Lapas. Berlandaskan UU Pemasyarakatan yang mengutamakan Narapidana lansia kebutuhan khusus dan kondisi kesehatan rentan agak layak mendapatkan perawatan maksimal dan dalam upaya tersebut Pemasyarakatan lebih menonjolkan segi prevensi khusus atau special dari segi prevensi umum.

1. Sesuai dengan RPJMN 2015-2019 pemerintah memperjelas bagaimana perawatan yang dimaksudkan melalui pemenuhan Hak-hak dasar Lansia dalam hal ini narapidana Lansia baik itu di tingkat pusat maupun daerah kemudian didukung dengan partisipasi masyarakat melalui penyuluhan,sosialisasi webinar yang meningkatkan kesadaran masyarakat lainnya mengenai kebutuhan 
perawatan dan perlakuan khusus bagi lansia. Hak dasar berupa pemenuhan sandang, pangan dan papan, perawatan kesehatan, perawatan kerohanian, perawatan kemandirian dan perawatan bildang ilmu dan pengetahuan.

2. Salah satu bagian dari perawatan adalah perhatian. melakukan survei dan analisis kebutuhan yang dibutuhkan, kemudian klasifikasi berdasarkan angka rentannya. Perhatian dengan membangun interaksi yang baik pada kesehariannya, karena satu hal penting yang Narapidana lansia butuhkan adalah perhatian dan di dengarkan. Komunikasi sehari-hari, tegur sapa saja sudah merupakan upaya perawatan secara bertahap yang dilakukan Pemasyarakatan.

3. Peningkatan kualitas pegawai Pemasyarakatan dalam hal kesehatan dan perawatan lansia,dimana petugas Pemasyarakatan dibekali ilmu praktis bagaimana penanganan bagi narapidana lansia,mengenal,memahami dan mengkondisikan diri bagi narapidana,menerima dan merangkul mereka karena yang tersirat dipikiran mereka adalah mereka tudak dierima lagi oleh keluarga dan masayarakat maka dianggap perlu,seorang petugas pemasyarakatan menjiwai kondisi nurani narapidana lansia tersebut.

4. RPJMN 2015-2019 ini jugamemperkuat modul atau skema perlindungan kondisi sosial yakni melalui pengesahan perundangan-undangannya. diperkuat dengan undang-undang yang sah bagaiamana mereka tetap mendapatkan perlindungan sosial dari masayarakat. Tidak di kucilkan, menghilangkan stigmanisasi dan konfilik kemasyarakatan lainnya. Karena secara psikologis mereka terhantui dengan gelar penjara yang mereka sandang, mereka juga merasa kecil diri ketika berhadapan dengan lingkungan sosial lebih besar.

5. Perhatian pemerintah terhadap perawatan tersebut,tertuang dalam UndangUndang Nomor 11 Tahun 2009 tentang Kesejahteraan Sosial yang menjamin kesejahteraan kelompok marginal(rentan) didalamnya juga mengatur bagaimana pemenuhan kebutuhan dasar baik sandang,pangan dan papan Narapidana tersebut.

Maka dari itu perawatan ini melibatkan banyak aspek,mulai dari pemerintah,Pemasayarakatan dan para petugas,keluarga yang bersangkutan,masyarakat secara luas.Pada tahun 2005 hingga 2008 dengan dibentuknya Komisi Nasional untuk Lansia guna mengatasi permasalahan kehidupan lansia diikuti dengan peraturan pemerintah Indonesia bagi lansia sebagaimana tentang kesejahteraan lansia kesejahteraan lansia (Abikusno, 2007).

b. Layanan Kesehatan Narapidana Lansia

Undang-Undang Nomor 36 Tahun 2009 tentang Kesehatan sebagai upaya perhatian pemerintah kepada lansia dalam aspek kesehatan yang menjamin upaya peningkatan dan pemeliharaan kesehatan tanpa diskriminasi.Dalam Undang-undang ini pemerintah meringankan biaya kesehatan agar semua aspek masyarakat dapat menerima layanan kesehatan yang layak,akses layanan kesehatan yang terjangkau dan bagi seluruh 
masyarakat.Sama halnya di dalam Lapas melalui kelembagaan pemasyarakatan yang menyediakan klinik kesehatan Lansia dalam Lapas.

Permenkumham No. 32 tahun 2018 diatur bagaimana perlakuan terhadap Tahanan dan Narapidana Lansia. Pasal 2: Perlakuan terhadap narapidan dan tahanan lansia bertujuan pemenuhan kebutuhan dasar bagi mereka agar mendapatkan perawatan dan pemeliharaan khusus baik segi mental,fisik,kerohanian,kepribadian agar semuanya sesuai ketentuan peraturan perundang-undangan yang berlaku dimulai dari tahap assesment narapidana dan tahanan lansia,didata penyakit dan keadaan narapidana lansia agar mengetahui tingkat perawatan yang sesuai bagi mereka dan dikelompokkan dalam kelompok lanjut usia.Melakukann pendataan jumlah lansia yang sakit,obat-obatan yang kadaluwarsa dan pemasokan obat-obatan,yang nantinya dapat dipenuhi melalui kordinasi dengan Kalapas.Pemasyarakatan setidak sekali sebulan melakukan kajian ulang dan evaluasi pelayanan kesehatan narapidana dan pngecekan ulang seluruh alat dan obat-obatan di klinik Pemasyarakatan (Pahlevi, 2019).

Menjalin kerjasama dua atau lebih instansi terkait,seperti Puskesmas daerah,Rumah Sakit Umum dan Swasta, klinik dan layanan kesehatn lainnya yang sewaktu-waktu dapat mendukung layanan kesehatan di dalam Lapas. Kerjasama ini juga dapat membantu instansi terkait memberi bantuan kesehatan serti vaksinasi, Vitamin dan layanan pemeriksaan kesehatan rutin.Sejauh ini pelaksanaan pemeriksaaan kesehatan rutin dudah di lakukan di beberapa Lapas di Indonesia,meski belum seluruhnya namun secara bertahap sudah diperbaiki.Karena kesehatan Narapidana Lansia ini rentan maka layanan kesehatan yang tersedia harus di optimalkan.Mengutamakan Lnasia ketika pengobatan di klinik Pemasyarakatan agar penanganannya lebih baik dan optimal.

Beberapa contoh dan langkah konkret layanan kesehatan bagi Narapidana lansia:

1. Melaksanakan Kegiatan senam jantung yang mengantisipasi penyakit dan serangan jantung.

2. Bagi narapidana Lansia yang masih produktif perlnya olahrga rutin membakar kalori sebagai pencegahan diabetes dan kolesterol. (Biasanya Senam dan Olahraga yang di sediakan,di sesuaikan dengan kondisi masingmasing Narapidana)

3. Beri vitamin tubuh dan tulang seperti Vit-c dan susu Nutrisi protein tulang.

4. Rutin melaksanakan pengecekan tekanan darah, kadar gula dalam darah dan jantung.

5. Lakukan himbauan dan larangan menrekok dan konsumsi pantangan makanan.

6. Mberikan alat bantu pendengaran bagi mereka yang mulai tul,penyedian toilet duduk bagi narapidana yang sakit stroke, dan penyedian jalan ramp.

7. Menyediakan kursi roda bagi lansia diabilitas dan yang sulit bergerak dan jalan.

8. Sediakan pempers atau alat bantu untuk buang alir besar dan kecil. 
Yang menjadi komitmen pemerintah yakni memperhatikan biaya kesehatan,karena masyarakat masih terkendala di masalah biaya maka dari itu pemerintah mengupayakan minimalisr biaya dan mempermudah akses layanan kesehatan bagi setiap masyarakat Indonesia yang tentu harus disesuaikan dengan ketetapan peraturan.

Maka guna mencakup keseluruhan masyarakat Indonesia maka pemerintah mengakomodasi perlindungan dan jaminan kesehatan bagi lansia. Ditinjau dari aspek sarana dan prasarana, administrasi dan informasi, pemerintah melalui regulasi, yaitu Peraturan Pemerintah Republik Indonesia Nomor 4 Tahun 2017 dan Undang-Undang Republik Indonesia Nomor 11 Tahun 2009 tentang Kesejahteraan Sosial. Di Pasal 17 ayat 6 dijelaskan bahwa pelayanan yang disediakan adalah bertujuan memberikan aksesibilitas kepada lansia, terutama di tempat-tempat umum yang dapat menggagnggu atau bahkan menghambat mobilitas lanjut usia.

c. Implementasi Pemenuhan Hak Remisi Lansia

Remisi adalah pengurangan masa pidana yang diberikan kepada narapidana dan anak pidana yang telah berkelakuan baik selama menjalani pidana terkecuali yang dipidana mati atau seumur hidup (Indonesia, 1981). Sedangkan menurut PP No 32 tahun 1999 pada Pasal 1 Ayat 6 remisi adalah pengurangan masa pidana yang diberikan kepada narapidana dan anak pidana yang telah memenuhi syarat-syarat yang ditentukan dalam peraturan perundang-undangan.Maka dari itu Remisi diberikan dengan beberapa pemenuhan persyaratan bagi narapidana dan tidak semua Narapidana sewaktu-waktu dapat menerima remisi dan remisi yang diterimapun berbeda-beda.Sebagai upaya pemenuhan hak narapidana melalui Remisi inilah menjadi dambaan dan idaman seluruh WBP di Lapas.

Perlakuan khusus yang dimaksud dalam hal pemberian bantuan akses keadilan melalui pemulihan dan pengembangan fungsi sosial kemudian selama di dalam Lapas mereka mendapatkan perlingungan secara keamanan dan keselamatan. Pemberian bantuan secara akses keadilan dapat diberikan dengan memfasilitasi dan mendampingi dalam mendapatkan penasihat hukum,aplikatif dalam komunikasi dengan penasihat hukumnya.

Perlakuan khusus lainnya dengan mendampingi dan mengusahakan alternatif penjamin agar terhubung dengan lembaga bantuan hukum guna mendapatkan remisi.Remisi lansia yang diberikan kepada narapidana Lansia adalah setiap Hari Lansia Nasional yang diperingati setiap tanggal 29 Mei dan diberikan kepada narapidana dengan usia 70 ke atas.

\section{Syarat-Syarat Mendapatkan Remisi}

Narapidana atau Anak Pidana berhak mendapatkan Remisi apabila:

1). Narapidana berkelakuan baik, buktinya disertai dengan keterangan berupa, 2). Narapidana yang bersangkutan idak sedang menjalani hukuman disiplin pada kurun waktu 6 (enam) bulan terakhir, yakni terhitung sebelum tanggal pemberian Remisi; serta 
3). Mereka yang telah mengikuti program pembinaan yang diselenggarakan oleh Lapas dengan predikat baik.

Jenis remisi yang diterima narapidana lansia:

1. Remisi Kemerdekaan diberikan setiap memperingati Hari Kemerdekaan Republik Indonesia yakni tiap tanggal 17 Agustus (Nomor 174 Tahun 1999 tentang Remisi pasal 4 ayat 1 )

2. Remisi Khusus (khusus agama yang di anut)

3. Remisi kemanusiaan (Pasal 29 Permenkumham 3/2018) yakni untuk Narapidana yang dipidana dengan masa pidana paling lama 1 tahun, Berusia di atas 70 tahun; atau Menderita sakit berkepanjangan.

4. Narapidana yang mengikuti dan menjalankan kegiatan progran pembinaan dan pengarahan yang diselenggrakan Pemasyarakatan dengan baik dan tak bermasalah.

Lebih lanjut dijelaskan pemberian remisis harus sesuai KEPRES 174 yakni pemberian di tahun pertama sebagaimana dimaksud dalam ayat 1 (satu) kemudian di tahun kedua diberikan remisi 3 (tiga) bulan lalu remisi ke 4 pada tahun ke empat selama empat bulan,untuk tahun keempat dan kelimamasing-masing diberikan remisi 5 (lima) bulan yang terakhir di tahun keenam dan seterusnya diberikan remisi 6 (enam) bulan.

\section{Kesimpulan}

Upaya dalam implementasi penerapan sistem pemasyarakatan dengan memberikan hak-hak dasar warga binaan pemasyarakatan melalu pelayanan dan perawatan.Memperlakukan mereka sedikit lebih istimewa namun bukan atas dasar diskriminasi,melainkan kesejahteraan di usia mereka yang mana membutuhkan perhatian dan penanganan lebih serius karena mereka rentan terhadap penyakit,rentan akan perlakuan kasar dari narapidana umum dan rentan akan konsidi psikologis yang kian melemah. Perlakuan khusus lainnya adalah dengan memberi remisi di hari Lansia Nasional.

Namun beberapa fakta di lapangan berbicara bahwa mereka belum sepenuhnya diperlakukan khusus seperti kelompok rentan seyogiyanya.Hal ini dikarenakan sarana dan fasilitas yang masih dipenuhi dan jumlah petugas pemasyarakatan yang kian dibenahi agar nanti segera mengimplementasikan peratutan yang berlaku. Mengutakaman Hak Asasi Manusia bagi lansia melalui layanan mudah akses dan kesehatan terjangkau di lingkungan Pemasyarakatan.Hingga kini pemerintah perlahan memenuhi kekurangan yang ada kesejahteraan Narapidana Lansia. 


\section{BIBLIOGRAFI}

Abikusno, N. (2007) 'Long term care support and services for older persons: Case study of Indonesia'. Google Scholar

Akbar, M. (2019) 'Kajian Terhadap Revisi Undang-Undang No. 13 Tahun 1998 Tentang Kesejahteraan Sosial Lanjut Usia', Jurnal Mimbar Kesejahteraan Sosial, 2(2). Google Scholar

Dewi, W. P. (2019) 'Penjatuhan Pidana Penjara Atas Tindak Pidana Narkotika Oleh Hakim di Bawah Ketentuan Minimum Ditinjau dari Undang-Undang Nomor 35 Tahun 2009 Tentang Narkotika', Jurnal Hukum Magnum Opus. Universitas 17 Agustus 1945 Surabaya, 2(1), p. 276602. Google Scholar

Dimas, D. D. (2021) 'Pemenuhan Hak Kesehatan Bagi Narapidana Di Rumah Tahanan Negara Kelas Ii B Kebumen', Healthy Tadulako Journal (Jurnal Kesehatan Tadulako), 7(1), pp. 1-6. Google Scholar

Ernis, Y. (2017) 'Diversi Dan Keadilan Restoratif Dalam Penyelesaian Perkara Tindak Pidana Anak Di Indonesia (Diversion And Restorative Justice In Case Settlement Of Juvenile Justice System In Indonesia)', Jurnal Ilmiah Kebijakan Hukum, 10(2), pp. 163-174. Google Scholar

Indonesia, M. P. R. (2018) 'Peraturan Menteri Perhubungan Republik Indonesia', Jakarta: Menteri. Google Scholar

Indonesia, P. R. (1981) 'Presiden republik indonesia', Undang-Undang Republik Indonesia Nomor, 22, pp. 1-9. Google Scholar

Moeljatno, S. H. (2021) KUHP (Kitab undang-undang hukum pidana). Bumi Aksara. Google Scholar

Nur, H. (2017) 'Penghapusan Remisi Bagi Koruptor Dalam Perspektif Undang-Undang Nomor 12 Tahun 1995 Tentang Pemasyarakatan', Jurnal Hukum Mimbar Justitia, 1(2), pp. 550-571. Google Scholar

Pahlevi, F. S. (2019) 'Keadilan Hukum Dalam Peraturan Perlakuan Bagi Tahanan Dan Narapidana Lanjut Usia', Al-Syakhsiyyah: Journal of Law \& Family Studies, 1(1). Google Scholar

Panjaitan, P. I. (2009) 'Chairijah', Pidana Penjara Dalam Perspektif Penegak Hukum, Masyarakat Dan Narapidana. I. Jakarta: Indhill Co. Google Scholar

Papalia, D. E., Olds, S. W. and Feldman, R. D. (2007) Human development. McGrawHill. Google Scholar

RAMIDHA, R. S. (2011) 'Evaluasi Sanitasi Lingkungan Institusi Lembaga Pemasyarakatan Klas 1 Kota Madiun'. UNIVERSITAS AIRLANGGA. Google Scholar

Sitepu, C. B. A. (2021) 'Penanganan Masalah Rentan Narapidana Lanjut Usia dan Pembinaannya Di Lembaga Pemasyarakatan Narkotika Kelas IIA Karang Intan', Jurnal Syntax Transformation, 2(4), pp. 470-477. Google Scholar 
Sugiyono, D. (2013) 'Metode penelitian pendidikan pendekatan kuantitatif, kualitatif dan R\&D'. Alfabeta. Google Scholar

Walukow, J. M. (2013) 'Perwujudan Prinsip Equality Before The Law Bagi Narapidana Di Dalam Lembaga Pemasyarakatan Di Indonesia', Lex et Societatis, 1(1). Google Scholar

Wiyanto, R. (2012) Asas-Asas Hukum Pidana Indonesia. Mandar Maju. Google Scholar

\section{First publication right:}

Jurnal Syntax Fusion: Jurnal Nasional Indonesia

This article is licensed under:

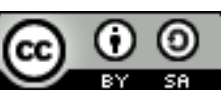

